\title{
Balinese Language
}

National Cancer Institute

\section{Source}

National Cancer Institute. Balinese Language. NCI Thesaurus. Code C153851.

A Malayo-Polynesian language spoken on the Indonesian island of Bali as well as northern Nusa Penida, western Lombok and eastern Java. 